\title{
Optical Analysis for the Estimation of Whole Blood Coagulation Time with Magnetic Particles
}

\author{
Jaehyun Lee, Hyoungsoon Choi, Dongwoo Jang, and Kie B Nahm ${ }^{\dagger}$ \\ Department of Physics, Hallym University, Chuncheon 200-702, Korea
}

(Received July 19, 2013; Revised manuscript October 10, 2013; Accepted October 24 2013)

\begin{abstract}
Prothrombin Time (PT) is used as a measure of blood coagulation time. An optical analysis of the signal generating mechanism is described here for the reflection-type arrangement. Thromboplastin added into serum or whole blood initiates the coagulation process. We added a sufficient amount of magnetic particles into the sample before adding thromboplastin and subjected the mixture to a rotating magnetic field. The laser light gets reflected in a periodically modulated fashion with respect to the magnetic field rotation. Analysis of this decaying modulation could produce a reasonable coagulation time. We also introduce a simulation model to explain the signal generating mechanism using LightTools. ${ }^{\text {TM }}$
\end{abstract}

Keywords: Prothrombin time, Blood coagulation, Magnetic particle, Liquid surface model, Stray light simulation OCIS codes: (170.1610) Clinical applications; (170.1470) Blood or tissue constituent monitoring; (120.4640) Optical instruments

\section{자성 철 가루를 이용한 혈액 응고시간 측정법의 광학적 해석 \\ 이재현 · 최형순 · 장동우 · 남기봉 \\ 한림대학교 전자물리학과 \\ (우 200-701 강원도 춘천시 한림대학길 1}

(2013년 7월 19일 받음, 2013년 10월 10일 수정본 받음, 2013년 10월 24일 게재 확정)

\begin{abstract}
본 논문에서는 혈액의 응고 시간을 나타내는 잣대로 활용되는 PT (prothrombin time)를 반사광을 이용하여 측정하는 방법에 대한 광학적 분석이 기술된다. 혈액에 일정량의 thromboplastin을 정량 추가하면 혈액의 응고 과정이 진행된다. 응고 시간을 측정 하기 위하여 혈액에 자성 철 가루를 혼입하고 자석을 회전시키면서 혈액 표면을 레이저로 조사하여 그 반사광의 변화를 측정하 였다. 이 신호를 분석하면 표준 값에 대응하는 PT 값을 환산할 수 있었다. 측정된 반사광 신호를 전산 모델링으로 나타내어 측정 원리를 분석한 결과도 같이 제시한다.
\end{abstract}

Keywords: 혈액응고시간, 혈액 응고, 자성 입자, 표면파 모델, 산란광 전산 모사

OCIS codes: (170.1610) Clinical applications; (170.1470) Blood or tissue constituent monitoring; (120.4640) Optical instruments

\section{I. 서 론}

척추 동물에서 혈액의 응고 현상은 혈장 내에 섬유소 형태 의 피브린(fibrin)이 형성되면서, 이 섬유질 단백질이 혈구들 을 얽어 매면서 고형화하는 과정이다. 이 과정에는 수 십 종 의 물질들이 관련되어 있으며, 각 물질들은 혈액이 혈관 외 부로 노출되는 순간부터 정해진 프로그램에 따라 단계적으 로 피브린을 형성한다. 이런 과정을 거치면서 혈액이 응고되 는 시간은 PT(Prothrombin Time), PPT(Partial PT), INR(International normalized ratio) 등 여러 수치 형태로 가공되어 판
독 자료로 활용된다. ${ }^{[1]}$

위 방법론들은 대부분 혈구를 제거한 혈장을 시료로 사용 하는 기법들이다. 따라서 사용자는 측정 전에 혈구 제거를 위해 원심분리 공정을 거쳐야 하기 때문에 전문 설비를 갖춘 검사실에서만 검사를 시행할 수가 있다. Oberhardt ${ }^{[2]}$ 은 시료 (혈액 또는 혈장)에 자성 철 가루를 혼입하고 이들 가루를 외부 자기장으로 조절하면서 반사광을 측정하는 방법으로 위와 같은 전처리(前處理)가 필요 없는 혈구 응고시간 측정 법을 소개한 바 있다. 이재현 등은 $100 \mathrm{um}$ 두께의 전혈에 thromboplastin을 첨가한 뒤 광 투과율을 측정하여 전혈로부

${ }^{\dagger}$ E-mail: kbnahm@hallym.ac.kr

Color versions of one or more of the figures in this paper are available online. 
터 PT를 측정할 수 있는 가능성을 입증한 바 있다. ${ }^{[3]}$

본 연구에서는 자성 철 가루를 첨가하는 방식을 일부 재현하 여 보고 그 과정에서 측정이 이루어지는 부분의 광학적 현상을 광산란 흥내내기를 통하여 구하고 이를 측정치와 비교하였다.

\section{II. 혈액 응고와 PT}

혈액의 응고는 혈액이 외부에 노출 된 경우에도 물론 진행 되지만, 내부적 원인에 의해서도 진행되는 경우가 있어, 이 렇게 체내에 형성된 응고물을 혈전이라고 한다. 혈액의 응고 과정은 다수의 생화학 물질들의 연쇄 반응에 의해 진행되는 것으로 현대 의학은 설명하고 있다. 그림 1 은 그 응고 과정 을 도식적으로 나타낸 것이다. 그림에서 I XIII 로 나타낸 것 은 응고인자, 즉 혈액의 응고 과정에 관여하는 여러 가지 단 백질과 효소를 나타내는 표준 기호들이다. 외인성 응고 과정 의 경우를 예로 들자면, 생체 조직 파괴 시 나타나는 $\mathrm{TF}$ (tissue factor) 단백질에 의하여 VII 인자가 활성 형태인 $\mathrm{VIIa}$ 로 바뀌고, 이들이 X 인자를 활성화 형태인 Xa 인자로 변화시킨다. 이러한 일련의 과정들이 순차적으로 진행되고 나면 마지막 단계에서 fibrinogen이 fibrin으로 바뀌면서 섬유 조직이 혈구들을 그물처럼 감싸는 구조물이 생성된다. 그림 2는 이러한 과정에 의해 형성된 응고물을 나타낸 것이다. PT 는 이 외인성 경로의 이상 유무를 정량적으로 나타내는 지수 로 활용된다. ${ }^{[4]}$ 건강한 사람의 경우 이 값은 $12 \sim 13$ 초 대역에 분포한다.

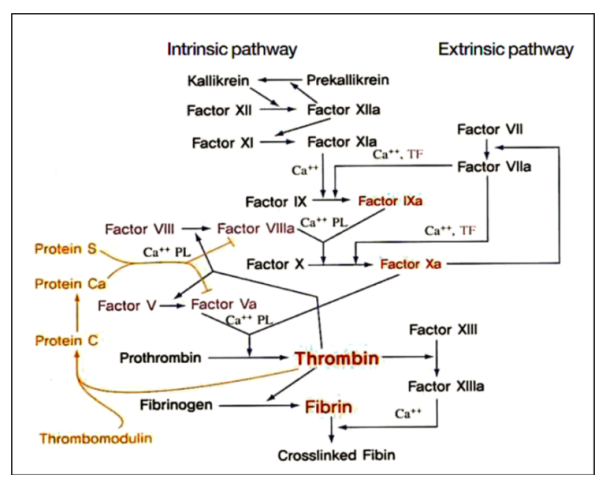

FIG. 1. Blood coagulation pathways. The intrinsic process represents the formation of thrombus, while the external the coagulation. Source: Reference ${ }^{[4]}$

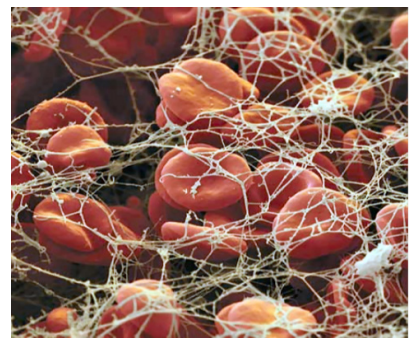

FIG. 2. False color image of red blood cells intertwined by fibrins [Encyclopedia Britannica online].

\section{III. 응고시간 측정 실험}

건강한 혈액은 대기에 노출되면 서서히 응고가 진행된다. 이 과정은 그림 1 의 외인성 경로를 따르는 과정이다. 보통 외부 출혈이 지혈되는 정도의 시간이 지나면 시료 혈액도 응 고하지만, 측정 실험실에서는 이 과정을 가속화하기 위하여 트롬보플라스틴을 사용한다. 즉 외인성 응고과정을 따르자면 인자 VIII, X, V 등이 작용한 뒤에 프로트롬빈이 분비되는데, 임상측정에서는 시료에 트롬보플라스틴을 첨가하여 이 과정 을 가속시킨다. 트롬보플라스틴은 $\mathrm{Ca}++$ 와 함께 프로트롬빈 이 트롬빈으로 변화하는 과정을 시작시키는 효소이다.

\section{1. 실험}

본 연구에서는 전혈 시료에 자성 철 가루를 혼입하고 이 를 회전하는 자기장에 노출하여, 시료 내에서 자성 철 가루 들이 만드는 침상 구조물이 자기장에 따라 누웠다가 일어나 는 과정을 되풀이 하도록 하였다. 자석은 $0.6 \mathrm{~Hz}$ 로 회전시켰 는데, 이 값은 혈액에 잠긴 철 가루가 자기장의 변화에 따라 움직일 수 있도록 선험적으로 선정한 값이다, 이 방법은 Oberhardt $^{[2]}$ 가 제안한 방법과 원칙적으로는 다르지 않다. 본 연구에서는 신호 발생 기전을 파악하기 위하여 자성 철 가루 를 [2]에서 제안한 $5 \sim 50 \mathrm{mg} /(\mathrm{ml}$ reagent)보다 과량으로 첨가 하였다 $(1.0 \mathrm{~g} / \mathrm{ml})$. Oberhardt는 철 가루의 평균 크기를 $5 \mu \mathrm{m}$ 이하로 하는 것을 권장하였는데, 본 연구에서는 $110 \mu \mathrm{m}$ 정도 의 철 가루를 사용하였다. Oberhardt 등은 트롬보플라스틴 제제를 건조상태에서 혈장과 반응시키는 방식을 사용하였으 나 본 실험에서는 트롬보플라스틴을 액상으로 사용하였다. 그림 3 과 그림 4는 본 실험에 사용한 시료 홀더 및 설비 전 반을 보인 것이다.

전혈에 자성 철 가루를 혼입시키고 이를 자기장에 노출시키 면 자기장의 방향에 따라 철 가루들이 정렬하게 된다. 그림 5 는 이 과정을 가시적으로 나타내기 위하여 전혈 대신 증류수 를 이용하여 관찰한 결과이다. 아래에 위치한 자석의 회전 방 향에 따라 증류수 속에서도 철 가루 침상 구조물 방향이 변화 하고 있음을 확인할 수 있다. 전혈 속에 혼입된 철 가루도 유 사한 거동을 나타낼 것으로 예상되지만, 혈액이 응고되기 시 작하면 점도가 증가하고 이에 따라 철 가루 방향의 전환이 점 차 어려워지게 될 것으로 예상된다. 이러한 철 가루 침상 구조 물의 배열은 산란광 분포에 영향을 줄 것으로 기대하게 되며, 그림 3의 설비는 이 변화를 기록하도록 설계하였다.

\section{2. 측정 결과의 이해}

그림 6 은 그림 3 의 설비를 이용, 철 가루가 혼입된 전혈 시 료에 트롬보플라스틴을 정량 첨가한 뒤 자석을 회전시키면 서 산란광의 세기를 시간에 대하여 측정한 결과이다. 혈액 내 철 가루의 분포와 이동 양태에 따라 전체적인 형태가 다 르게 형성되기도 하지만, 여기에서는 예상되는 모델의 작동 


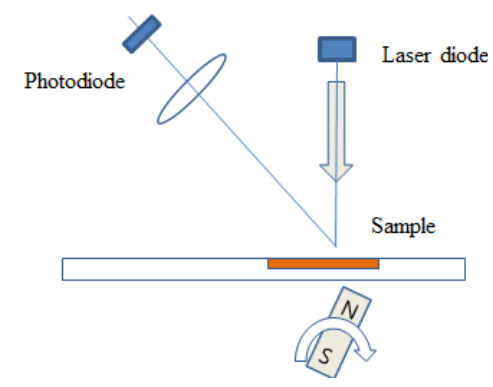

FIG. 3. Layout of the testing apparatus. See Fig 4 for the sample holder.

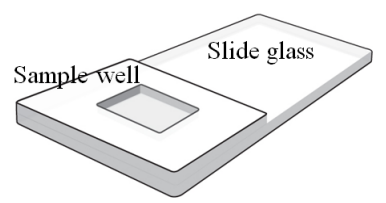

FIG. 4. Sample holder made of clear tapes on the microscope slide glass. The sample well dimension is $15 \times 15 \times 1 \mathrm{~mm}^{3}$. Sample mixture was prepared with $0.1 \mathrm{ml}$ whole blood and $\sim 0.1 \mathrm{mg}$ of magnetic particles
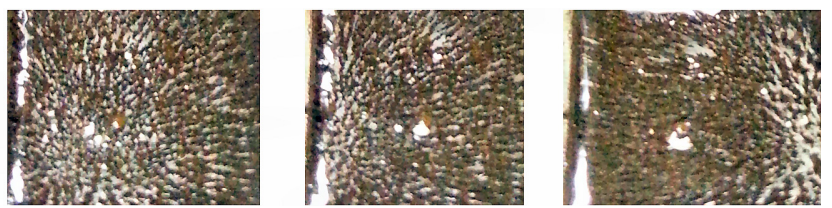

FIG. 5. Collective behavior of magnetic particles in water. Variation in the distribution pattern is observable with respect to the rotation of the external magnet. Average diameter of the particle was around $\sim 110 \mu \mathrm{m}$.

기전과 잘 부합되는 결과를 제시하여 이를 전산 흥내내기의 모델로 사용하기로 한다.

이 측정에서는 전혈에 트롬보플라스틴이 가해져서 반응이 시작되는 시점을 정확하게 정의하기가 어려운 면이 있지만, 이를 그림 6으로부터 추정할 수는 있어 보인다. 즉 산란광 측정용 디지털 변환기(ADC)가 8 bit 용량을 가지고 있기 때 문에 그림 6 에서 대략 $\times=80$ 지점까지는 혈액의 응고에 의한 영향이 관찰되지 않는다고 할 수 있다. 검은 점으로 나타낸 이 구간의 두 점 값은 거의 같으면서 검출기 한계인 8 bit 최 대값 이내이기 때문에 이 값들이 검출기 포화에 의해서 같게 나온 것은 아닌 것으로 판정할 수 있다. 추론하자면 이 혈액 의 응고 현상은 $\times=80$ 지점을 시작점으로 하여 진행된다. 그 림 6의 수식 맞춤을 이용하면 이 시료의 응고시간을 추정할 수 있다. 이 식에서 응고에 의한 영향을 나타내는 부분은 지 수함수 부분이다. 반응 시작점 $\times=80$ 이전의 두 점을 제거하 고 곡선 맞춤을 시행하면 그 감쇠부분은 다음과 같다.

$$
R=6.96 \times 10^{1} e^{\left(-2.22 \times 10^{-3} x\right)}
$$

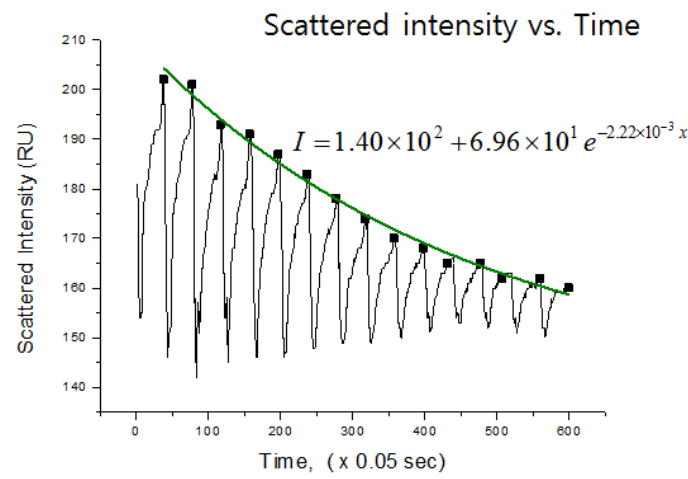

FIG. 6. Time dependent variation of the reflected light as the magnet rotates. PT can be derived from the exponential term of the curve represented here with a green line.

반사율 $\mathrm{R}$ 이 $1 / 2$ 이 되는 시점을 응고시간으로 본다고 하자. 식 (1)에 의하면 그 지점은 $12.3 \mathrm{sec}$ 시점이 된다. 측정에 사 용된 혈액의 응고 시간은 표준 임상기기에서 $12.5 \mathrm{sec}$ 로 확 인되었다.

\section{IV. 전산 흉내내기를 이용한 해석}

그림 6에 나타낸 바와 같은 측정 결과가 발생하는 기전은 명확하게 기술된 바가 없다. 자성 입자 배열의 변화에 따른 산란광의 분포 변화가 주기적으로 보일 개연성이 있는데, 이 단원에서는 이를 물리적 관점에서 분석하고자 하였다.

본 실험에서는 혈액과 철 가루 비가 무게비 $1: 1$ 에 근접 할 정도로 철 가루가 과량으로 투입되었다. 이는 Oberhardt ${ }^{[2]}$ 가 제안 한 양 $(5 \sim 50 \mathrm{mg} /(\mathrm{ml}$ reagent) $)$ 을 훨씬 초과하는 수치이다. 현재 상태의 측정 설비에서는 제안된 정도의 철 가루를 투입 할 경우에는 산란광 신호가 재현성 있게 관찰되지 않아 그 양을 현재 수준으로 올려야만 하였다. 철 가루가 누웠다가 서서히 기립하는 단계가 되면 혈액의 표면이 부분적으로 융 기하고 있으며, 이 융기된 부분이 철 가루의 회전에 따라 시 료 표면을 이동해 가는 것이 관찰되었다. 저자들은 이 융기 된 파동의 이동이 반사광의 주기적 변화를 유도한다는 가정 을 세우고 이를 전산 흥내내기를 통하여 검증하기로 하였다. 전산 모델은 액체 표면을 따라 높이 $1.0 \mathrm{~mm}$ 의 원통형 수 면파가 원통 길이에 수직한 방향으로 이동하는 것으로 하였다. 자석의 각도와 이 원통파의 중심점 위치 사이의 관계는 설정 하지 않았다. 이는 자석 자체가 축대칭성이 없는 형상을 하 고 있어서 자석의 “각도”를 엄격하게 정의할 수 없었기 때문 이다. 그러나 본 모델에서는 자석의 회전에 의해 발생하는 혈액 표면의 융기 파동이 그 연구 대상이어서 자석의 각도는 모델에 설정할 필요성이 없었다. 또한 이 모델에서는 혈액 내부의 철 가루에 대한 고려는 시도하지 않았다. 모델의 구 성 목적이 융기한 원통형 파형에 의한 산란광의 분석에 있었 으며, 자성 철가루는 그 융기 파형을 만들어 내는 기전으로 만 설정하였기 때문이다.

흥내내기에는 Synopsys사의 LightTools 8.0 을 이용하였다. 
그림 7은 설정한 산란광 발생 시스템의 LightTools 모델이다. 원기둥 모양의 파동을 시료 홀더 한 쪽 끝에서 반대 방향으 로 $1 \mathrm{~mm}$ 씩 이동시키면서 각 지점에서 예상되는 산란광의 세기를 상대 단위로 계산하였다. 원기둥 파형의 각 위치마다 광원에서 $10^{6}$ 개의 광선이 직하방으로 출발하는 것으로 하였 고, 산란 반사된 광을 고정 각도에 위치한 검출면에 도달하 도록 하여 그 개수를 상대 비교하도록 하였다. 그림 8은 자 석을 회전시키면서 측정한 산란광의 분포와 흥내내기 결과 를 비교한 것이다. 그림 8의 실측 자료는 그림 6에서 나타나 는 연속 파형 중 하나를 선택 하여 확대한 것으로, 자석의 각도와 원기둥 파형의 위치를 바로 정확하게 연계시킬 수는 없지만 대체적인 상관관계가 존재하는 것을 확인할 수 있다. 즉 그림 6에 나타나는 파형은 자성 입자들의 배열 변화에 의 한 효과가 있을 것으로 추정되지만 혈액의 이동 표면파에 의 해서도 그러한 신호가 발생하고 있음을 알 수 있다. 그림 8 의 각도는 자석의 상대적인 각도이다. 실험에서는 연속적으 로 자석을 회전시키는 펄스를 발생시키고 이 펄스의 수로 자

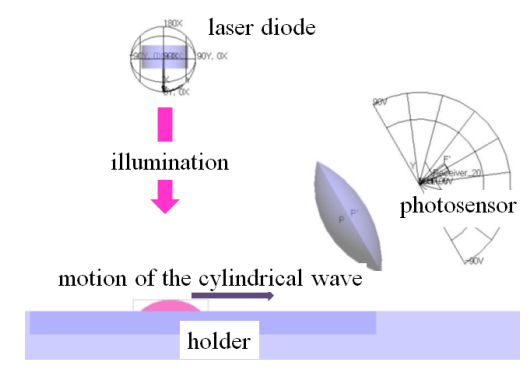

FIG. 7. Computer model for scattered light analysis by a traveling cylindrical liquid wave.
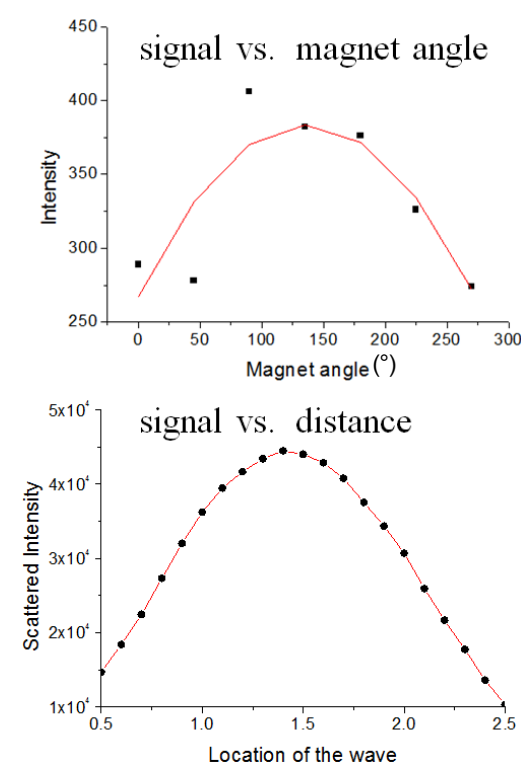

FIG. 8. Comparison of the measurement, with respect to magnet angle, (top) with the simulated result in terms of the location of the center of the cylindrical wave. The magnet angle here is a relative angle.
석의 각도를 상대적으로 어림한 것이다. $300^{\circ}$ 이상의 지점에 서는 철 가루들이 어느 특정 각도에서 더 이상 움직이지 않 는 것으로 판단되었다. 실험에 사용한 자석이 균질한 구조를 가지지 않은 형상이어서 회전 축에 대칭성 있는 구조를 구현 할 수 없어 $180^{\circ}$ 를 중심으로 한 대칭성이 발현되지 않은 것 으로 판단된다.

\section{V. 결 론}

혈액 응고시간을 측정하는 임상적 기법 중에서 자성 철 가 루와 반사광을 이용하는 방법을 실험적으로 검증하였다. 철 가루가 혼입된 전혈 시료 아래에서 회전하는 자석의 자기장 에 의해 액체시료 내의 철 가루들이 집합적으로 재배치되는 현상을 관찰하였으며, 산란광 역시 시간에 대하여 주기적으 로 감쇠하는 형태로 변화하는 것을 확인하였다. 지수적으로 감쇠하는 산란광 유형을 분석하여 혈액의 응고시간을 12.3 초 로 환산하는 바, 이는 표준 방법으로 측정한 12.4 초와 사실 상 오차범위내에서 일치하는 것으로 볼 수 있었다.

이러한 신호가 발생하는 기전으로 일차적으로 주목된 것은 물론 자성 입자 정렬상태의 주기적 변화였으나, 가시적으로 관찰된 대상은 혈액 표면에 발생하는 표면파였다. 자성 입자 들의 농도가 높을 경우 표면에는 누운 원기둥 형태의 파동이 이동하는 것이 관찰되었다. 물론 이 파동은 시료 홀더의 가 장자리에 충돌한 후 반사하는 등 그 운동 분석이 복잡성을 띄기는 하지만, 본 연구에서는 이를 이동하는 원기둥 꼴의 파동으로 모델을 설정하였다. 시료 홀더의 한 쪽 끝에서 출 발한 원기둥 파동이 이동하는 과정을 LightTools 산란광 분 석 프로그램으로 전산흥내내기를 수행하였다. 이 실험에서도 측정 결과와 유사한 형태의 신호가 발생하는 것이 확인 되 어, 혈액 내 자성 입자들의 집합적 운동에 의해 발생하는 표 면파가 반사/산란광의 분포가 주기적으로 변화하게 하는 인 자임을 확인할 수 있었다.

\section{References}

1. S. Kitchen, A. McCraw, and M. Echengucia, Diagnosis of Hemophilia and Other Bleeding Disorders-Laboratory Manual (World Federation of Hemophilia, Montreal, Canada, 2010).

2. B. Overhardt, "Method for performing coagulation assay accurately, rapidly and simply, using dry chemical reagents and paramagnetic particles," US Patent 5110727 (1992).

3. J. Lee and K. B. Nahm, "Measurement of blood prothrombin time by optical transmission," in Proc. Student Poster Presentation in KPS Conference (Busan, Korea, Oct. 2011).

4. C. J. Lyu, "Introduction to coagulation system," J. Korean Soc. Neonatol. 18, 1-5 (2011). 